Accepted version

Citation information:

Peters, L. E. R. (2021). Beyond disaster vulnerabilities: An empirical investigation of the causal pathways linking conflict to disaster risks. International Journal of Disaster Risk Reduction, 55, 102092. https://doi-org/10.1016/j.ijdrr.2021.102092

\title{
Beyond disaster vulnerabilities: An empirical investigation of the causal pathways linking conflict to disaster risks
}

Laura E. R. Peters

University College London

Oregon State University

laura.peters@ucl.ac.uk

\begin{abstract}
From Afghanistan to Zimbabwe, we see evidence of an ever tighter coupling between natural hazard-related disasters ("disasters") and violent social conflict ("conflict"), but scholarship often focuses on conflict only as a consequence and not a driver of disaster. Disaster studies scholarship has established that conflict can create or exacerbate disaster vulnerabilities and that disasters and their impacts are concentrated in conflict-affected and fragile contexts. Yet, research at the intersection of disaster and conflict has not comprehensively investigated the causal mechanisms that lead from conflict to disaster beyond the creation of vulnerabilities, and in global policy and practice, conflict is conventionally considered outside the purview of disaster risk reduction (DRR). To better understand how conflict drives disaster risk, this research gathers qualitative empirical evidence from 32 in-depth interviews with DRR experts in 25 conflict-affected countries across South Asia, the Middle East, and Africa experiencing diverse internal conflict conditions, from violent protests to civil war. The findings show that conflicts do not just comprise the context for disasters, but also contribute to disaster risk creation and amplification through diverse causal pathways related to hazards, exposure, vulnerabilities, and coping capacities, and do so at multiple institutional and temporal scales. This research provides a new foundation built on DRR practitioner expertise for more comprehensive and targeted DRR strategies and approaches in conflict-affected regions with the goal of ensuring that those experiencing the disaster-conflict nexus are not left behind by DRR programming.
\end{abstract}

Keywords: disaster risk reduction; disaster knowledge; disaster response; vulnerability; conflict; violence 


\section{Introduction}

The co-occurrence of natural hazard-related disasters ("disasters") and violent social conflicts ("conflicts") is neither new nor extraordinary, and contemporary history has produced numerous examples of disasters occurring in conflict zones across geographic regions. In 2015, Tropical Cyclones Chapala and Megh pummeled war-torn Yemen (2015-present) with rain and contributed to major flooding, which displaced approximately 47,000 people in a population where $80 \%$ are in urgent need of humanitarian assistance (UNICEF Yemen, 2015). Afghanistan has been ravaged by decades of interconnected wars alongside earthquakes, floods, drought, landslides, and avalanches (Mohanty et al., 2019), which together have escalated the population in need of humanitarian assistance to 6.3 million people in 2018 (OCHA, 2018). Similarly, South Sudan has a turbulent history of civil and communal conflict intermingled with recurring floods and droughts, and a combination of severe flooding and intercommunal clashes in 2020 killed and displaced thousands of people already living in a humanitarian crisis (OCHA, 2020). For decades, scholars have worked to unpack the potential relationships between disasters and conflicts across diverse case studies and spatial scales. Despite a lack of decisive conclusions (Ide et al., 2020; Peters \& Kelman, 2020), the idea that disasters principally incite or intensify conflicts has taken hold in policymaking and promoted top-down (Alexander, 2020) and securitized (Hartmann, 2010) approaches to managing disasters and climate change.

In conceptualizing disasters as exogenous events that can trigger social unrest and political instability, insufficient attention has centered on how disasters may also emerge from histories, patterns, and dynamics of conflict. Disasters literature has offered the foundations for how conflict contributes to disaster vulnerabilities (Hewitt, 1983; Lewis, 1999; Wisner et al., 2004), but notwithstanding these theoretical insights we still know little about how conflicts contribute to the creation of disaster risks (Siddiqi, 2018; Walch, 2018). Despite the potentially increased need for disaster risk reduction (DRR) in conflict-affected regions, conventional DRR does not take conflict into consideration in its design and delivery (Peters, Peters, et al., 2019), and it is built around the normative assumption that peace is a necessary precondition for action (Peters, Holloway, \& Peters, 2019). DRR is often seen as impossible to implement particularly in regions embroiled in high-intensity conflict, and disaster-related activities are relegated to the provision of limited disaster response and relief (Mena \& Hilhorst, 2020). This lack of knowledge and targeted action leaves the roughly 1.8 billion people living in war-torn and fragile areas (OECD, 2018) most likely to be left behind in the global commitment to DRR (Peters, 2019) while they disproportionately endure preventable disaster-related losses to life, livelihoods, health, and assets.

For the global DRR community to advance its ambitious agenda to substantially and equitably reduce disaster mortality, economic loss, and damage to critical infrastructure through a culture of prevention (UNISDR, 2015), it must grapple with the role of conflict in driving disaster risks. This article builds on conceptualizations of how conflict contributes to disaster vulnerabilities to empirically identify the diverse pathways through which conflict can contribute to disaster risk creation. I analyze qualitative data on the conflict-disaster nexus collected from in-depth interviews with DRR experts working at the frontlines of disaster and conflict in 25 conflict-affected countries in Africa, South Asia, and the Middle East. My findings highlight the value of grounded perspectives at the intersection of theory and praxis that are so often overlooked in both academic research and global policy. This work sheds new light on how 
disasters develop and manifest in places embroiled in politically motivated internal conflict, including violent protests, communal violence, civil war, and post-conflict settings, and establishes a foundation for developing DRR policy and practice that goes beyond conflictsensitivity to become inclusive of conflict-affected populations and landscapes.

\section{Background}

\subsection{Disaster risk creation}

The United Nations General Assembly (UNGA, 2017, p.13) adopted the definition of a disaster as, "A serious disruption of the functioning of a community or a society at any scale due to hazardous events interacting with conditions of exposure, vulnerability and capacity, leading to one or more of the following: human, material, economic and environmental losses and impacts." This definition of disaster - also utilized by the United Nations Office for Disaster Risk Reduction (UNDRR) - integrates contemporary understanding of disaster risk based on Wisner et al. (2004) as follows:

disaster risk $=\underline{\text { hazard } \mathrm{x} \text { exposure } \mathrm{x} \text { vulnerability }}$ coping capacity

(see DasGupta \& Shaw, 2017). Though its constituent terms and the understanding thereof are constantly developing and evolving (Kelman, 2018), the disaster risk equation effectively captures that disasters are not single-factor or solely attributable to hazards.

Disasters are not natural but socially constructed (Ball, 1975; O'Keefe et al., 1976; Tiranti, 1977), and even so-called rapid-onset disasters, including those related to hydro meteorological and geophysical hazards, are embedded in long-term social processes (Kelman, 2018; Lewis, 1988). As such, disasters represent a continuation or extension of the underlying political, social, economic, and environmental dynamics and patterns at play even as they manifest serious disruptions in societal functioning.

\subsection{Conflict contributes to disaster risk creation}

Key to the production and mobilization of disasters are politics (Drury \& Olson, 1998), which may engage with and be affected by violent forms of social conflict ("conflict"). Conflicts affect no small number of people: $14 \%$ of the global population (one billion people) lived in active conflict zones in 2015 alone (UNFPA, 2015), and more than 2.3 million people - many of whom unarmed civilians - were killed in mainly internal forms of conflict from 1989 to 2017 (Pettersson \& Eck, 2018). Places experiencing protracted conflict (i.e., the prolonged violent struggle for basic needs by communal groups) (Azar et al., 1978) and state fragility (i.e., weak state authority, capacity, and legitimacy) (Carment et al., 2008) are characterized by sporadic episodes of violence that can extend across decades. Even the term "post-conflict" is arguably a misnomer due to the propensity of conflict-affected societies to relapse into war, instability, and other forms of violence (Brewer \& Hayes, 2011; Schuld, 2013). 
The legacies of conflict are not confined to instability and violence; the direct and indirect impacts of conflict extend into creating and sustaining disaster risks. Conflict affects how, where, and when disasters occur (Peters, 2018). Peters and Budimir (2016) found that 58\% of global disaster deaths between 2004 and 2014 occurred in the 30 most fragile and conflictaffected countries worldwide. Similarly, Marktanner et al. (2015) calculated that disaster deaths following armed conflicts were $40 \%$ higher than in non-conflict settings, and the authors estimated that conflict legacies contributed to approximately 700,000 disaster deaths from 1961 to 2010. The increased occurrence of disasters and their augmented impacts in conflict-affected countries are often explained through vulnerabilities: conflict creates disaster vulnerabilities through root causes (e.g., a history of conflict and the legacies of violence) and dynamic pressures (e.g., current wars or violence) that create unsafe conditions (Wisner et al., 2004).

The conflict-related root causes and dynamic pressures underlying drought-related famines in sub-Saharan Africa have been well scrutinized by scholars. Watts $(1983,2013)$ influentially examined the social causation of famine in 1970s Nigeria and described how postcolonial economic structures and politics functioned together to produce uneven manifestations of famine as "silent violence." De Waal (2018, p. 140) explained how the Dergue military regime caused drought-related famine in Ethiopia (1983-1985) and used it as a counterinsurgency tool to kill approximately one million people by way of starvation (see also Keller, 1992 and Lemma, 1985). There remain public perceptions that the Ethiopian government still uses disasters to advance its political goals (Desportes \& Hillhorst, 2020), with little room for non-state humanitarian agencies to navigate independent disaster response actions (Desportes et al., 2019). These analyses reveal that conflicts create structural vulnerabilities that are tied to disaster, but conflict actors may also nefariously create and mobilize disasters as a violent means to pursue political objectives.

\subsection{The effects of conflict on disaster risk creation extend beyond vulnerabilities}

Vulnerabilities may be a narrow lens through which to comprehensively understand the impacts of conflict on disaster risk creation. Hazard creation and exposure have recently come into focus as other potential pathways linking conflict to disaster risk. Conflicts can lead to environmental change and degradation, including agricultural abandonment and forest degradation (Baumann \& Kuemmerle, 2016), through impacts on ecosystems, institutional mechanisms, and circumstances that drive people to resort to unsustainable practices (Conca \& Wallace, 2009). Extensive forest destruction has been documented in conflicts around the world, from the Vietnam War (1962-1971) (Falk, 1973; Zierler, 2011) to Indonesia in the 1960s (Peluso \& Vandergeest, 2011) and El Salvador in the 1980s (Hough, 2016). The damage in Vietnam was so severe that it transformed ecosystems from forest to savanna (Falk, 1973), and the forests of El Salvador never regenerated (Hough, 2016). Deforestation as an extension of violence may contribute to the creation of hazards like drought in northern Uganda (Branch, 2018). This finding joins extant research demonstrating that deforestation increases the risk and severity of droughts (Bagley et al., 2014) as well as floods (Bradshaw et al., 2007) and landslides (Glade, 2003).

Conflict-era effects on environmental change and degradation can persist and even accelerate in post-conflict periods; following the peace agreement in 2016 between the Colombian government and the Fuerzas Armadas Revolucionarias de Colombia (FARC), forest 
disturbance increased by $50 \%$ in the Andes-Amazon Transition Belt between 2017 and 2018 due to land grabbing (Murillo-Sandoval et al., 2020). The most common landscape change in the areas immediately surrounding UNHCR refugee camps in Africa is deforestation associated with novel or expanded agricultural cultivation (Maystadt et al., 2020). Conflict-related human migration and displacement has also increased the exposure of conflict-affected populations to hazards like landslides and flooding in Colombia (Siddiqi et al., 2019). These alternate framings of hazard creation and exposure in concert with vulnerability open up broader and deeper understandings of how conflict and disaster interact.

\subsection{Missed opportunities for a conflict-inclusive DRR}

Most scholarship at the disaster-conflict nexus has investigated how disasters (including those influenced by climate change) may lead to heightened conflict risk (e.g., Hendrix \& Salehyan, 2012; Nel \& Righarts, 2008), intensity (e.g., Gawande et al., 2017; Linke et al., 2018), or duration (e.g., Eastin, 2016). Disasters have the potential to lead to disruptive - and sometimes violent - activities and to exacerbate or create social and political tensions principally by damaging property and infrastructure, destroying livelihoods, influencing human migration and displacement, and leading to fatalities (Brzoska, 2018). However, these effects may be at least in part mediated by pre-disaster conditions, the most influential of which are 1) income, resource endowments, and types and levels of economic activity, 2) ethnic conflict and exclusion, and 3) institutional setting (Brzoska, 2018). These pre-conditions have been identified in terms of how they shape the outcomes of disaster on conflict, but not how they may influence or contribute to the root causes of disaster.

The academic field of DRR does not often acknowledge the political causes of disaster risks (Lewis \& Kelman, 2012), and global DRR policy broadly ignores conflict (Peters, Peters, et al., 2019) or sees it as a context to navigate and not as a driver of disaster risk (Peters, 2019). The first priority for action in the Sendai Framework for Disaster Risk Reduction 2015-2030 is to understand disaster risk by drawing from scientific and local forms of knowledge so that it can be leveraged in effective preparedness and response; this priority underscores why it is critical to systematically and comprehensively build an understanding of how disaster risks manifest in conflict-affected regions.

The consequence of excluding conflict from how we understand and act upon disaster risk is that conflict-affected communities are left "off the radar" in both research and programming (Peters, Holloway, \& Peters, 2019, p. 31). Siddiqi (2018, p. S162) reflected, "It is strange to claim in the face of some 50 years of published work on the subject, that relatively little is still known about the ways in which disasters interact with conflict." This is in part because the body of disaster-conflict research has not thoroughly examined how conflict influences disaster risk. The present research seeks to fill this gap in knowledge by 1 ) empirically investigating and synthesizing the diverse causal pathways that link conflict with disaster risk creation, and 2) drawing from the experiential knowledge of DRR experts working in conflict-affected regions.

\section{Methods}

I conducted 32 in-depth semi-structured interviews between January and March 2019 with mid- and senior-level international and national non-governmental and intergovernmental 
organization (INGO/IGO) DRR experts (see Appendix A) in 25 conflict-affected countries in Northern Africa, Eastern Africa, Middle Africa, Western Africa, Southern Asia, and/or Western Asia (see Figure 1). This research focuses on internal forms of politically motivated conflict in active, protracted, fragile, and post- conflict stages. Initial participants were selected from attendees of the Africa-Arab Platform on Disaster Risk Reduction in October, 2018 in Tunis, Tunisia. Subsequent participants were recruited using snowball sampling methods, which are used to identify information-rich cases of interest (Miles \& Huberman, 1994) in difficult-to-reach populations (Bernard, 2011) including in conflict-affected areas (Cammet, 2006).

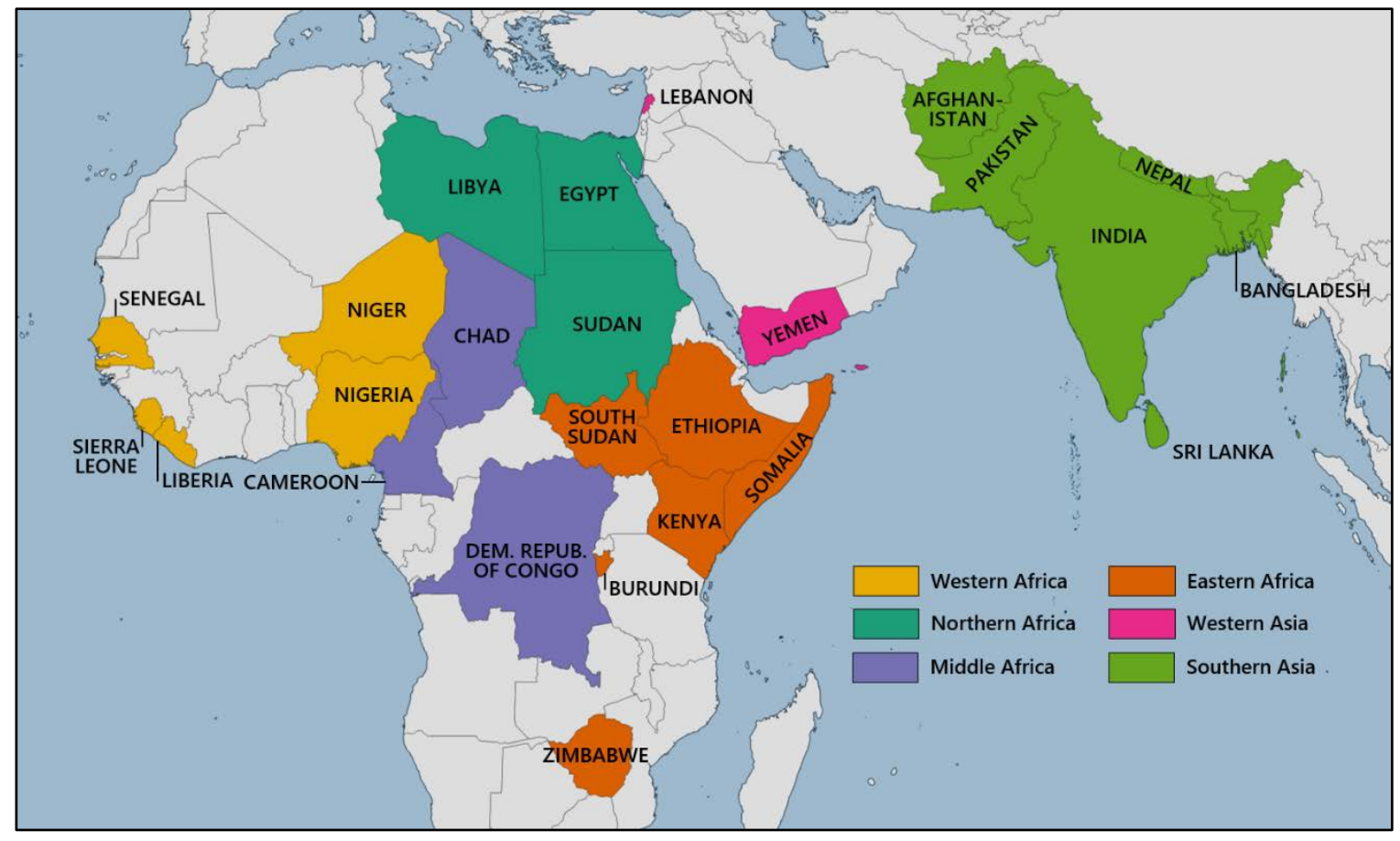

Figure 1. Study countries by geographic region. Countries were classified into regions based on the Standard Country or Area Codes for Statistical Use (M49) of the United Nations Statistics Division (UNSD).

I designed semi-structured interview questions (see Table 1) and asked tailored followup and clarifying questions. Interviews lasted approximately 90 minutes each and were remotely conducted in English through Skype and WhatsApp software, with the exception of one interview that was conducted in person. Remote interviews allowed me to overcome logistical challenges of gathering evidence from across broad geographies and in active conflict and crisis contexts that would otherwise be inaccessible. When research is not conducted in active or post-conflict regions, "knowledge and understanding tend to be stuck at the pre-war level" (Goodhand, 2000, p. 12). Remote interviews may provide additional methodological advantages by limiting emotional distress related to sharing sensitive topics (Mealer \& Jones, 2014). Interviews were voice recorded and later transcribed, and I recorded reflective notes (i.e., memoing) during the interview as well as during the review of transcriptions. Participant recruitment was discontinued when data saturation was achieved (i.e., when additional interviews did not lend themselves to new insights or knowledge) (Bertaux, 1981). 
Table 1. Semi-structured interview questions on the impacts of conflict on disaster and DRR.

1. Is conflict considered as a driver of disaster risks or disaster vulnerability? If so, how?

2. Do DRR projects operate differently because of conflict? If so, how?

3. Is it more difficult to conduct DRR in places that are currently experiencing or historically experienced conflict and violence than in places that are relatively stable and peaceful?

4. What are the key conflict-related challenges DRR projects face, and what are their impacts?

5. Are there any circumstances when conflict opens unique opportunities for DRR projects to be possible, effective, or successful? If so, how?

I synthesized interview data around established categories of disaster risk: hazards, exposure, vulnerabilities, and coping capacities. I identified corresponding subthemes such as livelihoods and infrastructure that emerged from my review of interview transcripts. The method of deriving general themes from the literature and adding subthemes throughout the course of the research in a blend of inductive and deductive analysis has been supported by Willms et al. (1990) (see also Bernard, 2011). I consolidated the individual passages into synthesized information, but I also sought to preserve the full diversity of contrasting perspectives. Participants expressed varied understandings of how conflict impacts disaster based on their professional experiences. Therefore, some sections or passages contradicted each other, and I noted which passages represented majority and minority viewpoints. Specific passages were accompanied by a unique region and interview number. When participants had professional experiences spanning multiple geographies, they were asked to specify the country and time frame associated with a particular response whenever possible. In some cases, participants made generalized comments, and the relevant passages retained multiple region codes along with the interview number.

I conducted participant validation by sharing a complete draft of the results with the participants over e-mail and soliciting feedback through a standardized questionnaire (Birt et al., 2016; Harvey, 2015). The participants were asked to review the results associated with their individual contributions for accuracy, and they were also invited to comment on the synthesized findings. I reviewed these comments and integrated those that were germane to the research objectives into the final findings.

\section{Findings}

Across participant experiences conducting DRR in 25 conflict-affected countries, participants collectively identified four main pathways through which conflict contributes to disaster risk creation: by constituting or creating hazards (Section 4.1), increasing exposure (Section 4.2), deepening vulnerabilities (Section 4.3), and impacting coping capacities (Section 4.4).

\subsection{Conflict creates hazards}

Conflict can compel conflict-affected people to inadvertently contribute to hazard creation when they are struggling to survive. For example, conflict-affected households may degrade environmental assets to secure basic survival needs like food, water, and housing. 
Environmentally destructive solutions can be the only ones immediately available or apparent in emergency settings when public services cease (see also Conca \& Wallace, 2009). These solutions may be necessary for survival, but when the government does not step in to offer socially and environmentally sustainable solutions, these micro scale and ad hoc solutions in aggregate can lead to significant hazard creation.

Conflict can also induce larger-scale environmental change and degradation. A participant described that conflicts in the Eastern Horn of Africa lead to the "destruction of forests and senseless environmental degradation," which may lead to more frequent or prolonged droughts in the region (EAfrica09) due to the loss of critical ecosystem services Similarly, a participant explained that land degradation, erosion, and poor agricultural practices resulting from conflict increase flood risk, which is exacerbated when humanitarian relief missions distribute plastic-encased food and water to conflict-affected populations who then discard the plastic waste in the waterways and block water flow (MAfrica14). Conflict-induced land use and land cover changes can occur quickly. For example, the mountain landscape in southeastern Bangladesh was rapidly and intensely modified to build roads, shelters, and other essential infrastructure to accommodate the large influx of Rohingya refugees into Cox's Bazar, and these changes contributed to increased flood and landslide risks (SAsia20; SAsia21) (see also Sarker \& Rashid, 2013).

Hazard creation can also occur through damaged, poorly constructed, or absent infrastructure, which are all more likely in conflict regions. Conflict and post-conflict regions are often characterized by a lack of investment in infrastructure (Schwartz \& Halkyard, 2006), and infrastructure failures, such as structural collapse or dam failure, triggered by natural hazard events can also lead to secondary or cascading hazards, such as explosions and fires (UNDRR \& ISC, 2020). Faulty structures carry a higher risk of collapse during hazard events like earthquakes, and infrastructure meant to mitigate risks may no longer serve their functions. One participant explained that water channels damaged and not well maintained due to conflict in Lebanon can convert a heavy rainfall into flash flooding: "This means that the disaster occurred not as a result of the rain but rather as a result of poor infrastructure stemming from conflict" (WAsia30).

\subsection{Conflict increases exposure}

Conflict-related forced displacement can increase natural hazard exposure for refugees or internally displaced people (IDPs) both when they are in transit and when they arrive at temporary and/or final destinations. Displaced people may use dangerous means of transportation to follow hazardous routes, and their precarious journeys may extend into days, weeks, or beyond. While in transit, they may sleep without shelter and supplies to keep them dry and warm/cool, and makeshift or temporary shelters often do not reduce exposure to even moderately hazardous weather conditions. The gap between resources and needs is augmented as displaced people tend to take nothing or very little with them. If people are displaced during harsh winter weather conditions and do not gain access to warm shelters, blankets, and heaters within 24 hours, they are at high risk of death from exposure: "The effect of cold weather could be to kill all the displaced population if they do not receive immediate support for a warm place and shelter" (SAsia18). (See Asfour, 2019 for a discussion of thermal comfort in post-disaster temporary housing in Gaza.) 
Displaced people may lack awareness of the risks they face in novel locations, and as a result, they may not take adequate measures to reduce their exposure to local hazards. When displaced people identify locations to set up shelter or settle, they often take what they can get rather than carefully select safer locations based on a robust risk assessment and informed decision making (EAfrica07). Without the luxury of time and information to evaluate safer locations, households and communities often settle in hazard-prone areas like dry river beds, valleys, or mountainsides. Even where hazards are known, displaced people may only be able to afford to settle in dangerous and peripheral locations, and their limited resources may force them to hastily construct low-quality shelters. These pathways to increased exposure are reinforced when conflict-affected governments lack the capacity to create or enforce zoning and building codes or when land developers opportunistically sell them hazard-prone and marginal land, as has also been documented in Colombia (Siddiqi et al., 2019). Because people displaced by conflict experience heightened exposure to hazards, they are also at risk of being subsequently displaced by disaster. Each displacement exposes them to additional hazards and deepens their vulnerabilities.

People who engage in planned migration in conflict-affected regions may face similar challenges surrounding exposure. For example, after the end of the Sierra Leone Civil War (1991-2002), people moved in droves to Freetown in search of livelihood opportunities or to "hide" from the past (WAfrica17), and the government did not restrict this movement in the spirit of reconciliation. Many people - but particularly poor migrants and conflict victims - built substandard shelters in unsafe places like floodplains. Now, nearly twenty years into a post-war peace, a mass relocation project to reduce hazard exposure for the original migrants and their progeny is politically and financially impossible (WAfrica17).

\subsection{Conflict increases vulnerabilities}

The bulk of conflict impacts on disaster risk creation is concentrated within vulnerabilities. One participant expressed, "Add conflict to a disaster situation, and it will make everyone very vulnerable, and vulnerability can open the door to a lot of tragedy" (MAfrica/WAfrica15). Several participants characterized how conflict-related vulnerabilities have all-encompassing effects on communities that take them "back to scratch" in terms of their development (EAfrica10). This section reviews how conflict proliferates and intensifies vulnerabilities through extreme violence, loss of livelihoods, forced displacement, and destroyed critical infrastructure and services.

\subsubsection{Extreme violence}

Extreme violence, including sexual and gender-based violence (SGBV) (encompassing sexual abuse and exploitation, rape, domestic violence, forced early marriage, genital mutilation, and trafficking), acutely threatens physical wellbeing, potentially resulting in physical disabilities and psychosocial traumas. One participant reported that conflict is one of the leading causes of short- and long-term disability in some regions in Kenya and provided examples of how people with varied disabilities are more vulnerable to disasters:

"They are the easiest to be swept away by flood waters, because a person who has a hearing impairment will not even hear the rumbling of a broken river bank. They will 
probably be sitting there as the flood water comes through. Someone who is visually impaired may not notice when others are fleeing. Some mental health conditions may hinder some from processing the information about what particular risks lie where I am right now. So, while the rest of the population is making quick calculations and shifting, they are not" (EAfrica07).

Households and community members may not have the capacity to assist those with disabilities in disaster settings, particularly when they themselves are faced with relentless conflict-related hardships (EAfrica07). The same participant relayed how a father in an IDP camp struggled to survive with his disabled adult son:

"A father specifically said he had become tired of carrying his son from one place to another whenever there is a conflict or whenever there is a flood...if it had been an animal, he would have slaughtered it. But because it is his son, he has to carry him around. 'I carry him, but it is hard to move him. I am getting older, and it is hard to carry him around"' (EAfrica07).

This participant concluded that community members would be even less likely to perform acts of assistance: "They would rarely consider carrying them, but they would simply save themselves... Most of the time, people with disabilities are left around" (EAfrica07).

Extreme violence is also detrimental to the psychosocial wellbeing of affected people, their households, and their communities. For example, survivors of SGBV sustain not only physical injuries but tremendous and enduring psychosocial impacts, including humiliation and "loss of dignity" (MAfrica/WAfrica15). Women and girls - and also men and boys - who experience SGBV may lose their sense of confidence and agency in being able to reduce their disaster vulnerabilities for themselves and their households (EAfrica/MAfrica04). One participant explained:

"The women who have started building confidence in themselves and looking forward and positively to the future, maybe experience rape, for example, and other forms of physical violence that take away that confidence they had and take them steps back in their development" (EAfrica/MAfrica04).

Extended periods of violence affecting a whole population can reorganize individual experiences into collective trauma. One participant recounted:

"Because of the repetitious nature of the conflict, people have become immune to the effect it has on them, and they have accepted that there is nothing they can do about it...There is a sort of immuneness [sic] or numbness to conflict...I would even call it 'communal numbness'” (EAfrica07).

Communities permeated with "communal numbness" often choose not to participate fully or at all in DRR programs even when they are available (EAfrica07), which suggests that this collective mindset both reflects and produces disaster vulnerabilities. 


\subsubsection{Loss of livelihoods}

Conflict disrupts or destroys livelihoods and business-related activities through targeted attacks, for example, when farms are deliberately set ablaze or businesses are looted. One participant reported, "Cattle attract conflict. The more cattle you have, the more conflict you're going to have" (EAfrica10). Business owners may also be coerced into "donating" their earnings to militias (SAsia24). To avoid impending attacks, affected households may migrate away from their sources of livelihood and abandon their farms and/or livestock. Conflict-affected communities are often characterized by abandoned farms and businesses, and abandoned or destroyed agricultural areas can have cascading consequences on regional food security. One participant described how people often liquidate their productive assets to meet emergency household needs:

"A farmer who has three cows may sell one of his cows to feed his family during the drought or during displacement. Or, upon returning to their house and finding that the house was looted, burned, and destroyed, they may sell even other household items like furniture or buckets or cooking parts and those kinds of things that would normally contribute to the household economy" (EAfrica04).

Such households may lose the ability to provide for future needs or absorb even small disaster losses.

\subsubsection{Forced displacement}

Forced displacement as well as immobility can increase disaster vulnerabilities. Mobility is an essential survival strategy in conflict settings, but even forced displacement may not be feasible when people do not know where to go, face conditions of extreme insecurity along routes of escape, or lack the resources or physical capabilities needed to flee (MAfrica/WAfrica15). Immobile or trapped populations may try to hide themselves instead, which increasingly puts them in a "very weak situation" (MAfrica/WAfrica15) (see Black et al., 2013). If and when trapped populations are able to flee, their starting point at departure and the conditions that surround them are typically much worse, and they may become even more vulnerable to disasters.

Displaced people typically leave most or all of their assets behind, including their livelihoods or sources of income. The resources they carry with them are quickly exceeded by their needs, and many displaced people urgently require humanitarian assistance. Even when they arrive in pre-existing settlements like camps, villages, or cities, they may not be able to gain access to basic services. Host communities with scarce resources may already be struggling to meet their own needs and lack the capacities and resources to respond to the enormous and immediate needs of new arrivals. Gaps in support may be institutionalized - for example, by instating cumbersome requirements to access services that displaced people cannot meet - where there are social or political tensions between host and arrival communities (SAsia18).

Displaced people are regularly excluded from disaster planning and decision-making processes (see also Peters, Eltinay, \& Holloway, 2019). As a result, their vulnerabilities, needs, capacities, and practices are not well integrated into DRR strategies and programming. For example, relief items do not always align with their needs and cultural preferences (SAsia21), 
and materials may not be distributed in languages they can understand (NAfrica03). Formal institutions may not integrate or even document the diverse practices of displaced people in their DRR approaches, and displaced populations may not understand or accept the services offered to them. Beyond this, the host communities do not benefit from diversified approaches to DRR. Disparate DRR practices between displaced populations and host communities may further entrench challenges of reducing community-level disaster risks.

\subsubsection{Destroyed critical infrastructure and services}

Physical infrastructure such as roads and bridges can be deliberately targeted or destroyed as collateral in violent conflict. Disaster mitigation infrastructure, like dams and floodgates, and infrastructural lifelines, like roads, hospitals, and water points, may be rendered unusable, and the households and communities that depend on them become more vulnerable to disasters. Even where infrastructure is intact, violence and insecurity can cut communities or specific groups off from critical resources. Entire conflict-affected populations can be left without services for long stretches of time, and people with injuries, illnesses, or other medical needs may not be able to access essential medical care (EAfrica07). Service disruption is often not evenly distributed, and people from certain groups may be attacked or killed when they attempt to access key infrastructure (EAfrica10).

Other infrastructure may be purposefully underdeveloped. Infrastructure related to information and communication technology (ICT) such as mobile phone technology, internet access, and WhatsApp, Facebook, and SMS messaging may be suppressed by authoritarianleaning governments in order to stymie political organization and action (WAfrica17), but these actions also carry consequences on effective DRR. For example, early warning systems depend on the accurate and timely collection and dissemination of information, and DRR programming depends on reliable communication between stakeholders.

\subsection{Conflict impacts coping capacities}

Conflict overwhelmingly decreases coping capacities by making civil society fragmented, government dysfunctional, and external actors inconsistent. One participant described, "It always feels like we are working against the current" (EAfrica/MAfrica04). Yet, there is also limited evidence that conflict can indirectly increase coping capacities.

\subsubsection{Fragmented civil society}

Civil society is central to building coping capacities, but civil society does not flourish in conflict conditions that engender disunity and destruction. Conflict can become insidiously "integrated into community functioning" (EAfrica10), and, over time, people in protracted conflict situations may even lose their belief in the concept of civil society as a space for collective action over shared interests and values (NAfrica02). People in conflict situations often associate themselves with a particular political party or social group rather than the broader society, and engaging with an opposing group can be construed as sympathizing with the enemy (MAfrica13).

Disaster risks grow as adversarial relationships hamper the identification and pursuit of collective solutions. Community-based DRR may be comparatively straightforward where there is social cohesion, a history of cooperation, and a similar way of understanding disaster risks 
(EAfrica07), but this is not the case where people define themselves more by their divisions. One participant described,

"It is only when you introduce the otherness that usually underlies most conflict, then that shifts the balance and makes it a lot more difficult to get that consensus [needed for DRR]" (EAfrica07).

When consensus is elusive, inclusive processes may be eschewed in favor of quick and unilateral decision making. Processes of convenience are likely to marginalize certain groups from decision-making processes. For example, when women are not included in local disaster management committees, they are not provided with training and information, and interventions are not designed to suit their vulnerabilities and capacities (SAsia24). When certain people are not included in the process surrounding DRR, they may not even be fully aware of disaster risks. One participant explained, "Often the weakest sections do not get to know anything about what is going on, so even the basic things like risk communication, they are not even included" (SAsia22). When those with special needs and their advocates are left out of planning processes, design factors may prevent their access to services. For example, a participant explained that people who are visually impaired or wheelchair bound may not be able to stand in aid distribution lines (EAfrica07).

Civil society groups may not exist or serve prosocial functions when the population is preoccupied with conflict-related activities. According to one participant, areas in Kenya steeped in conflict "are not at that stage where you could easily start a women's group or a youth group" (EAfrica07). The same participant shared that youth are taught to shoot guns when they are very young, so a youth group focused on DRR "would be the last thing they would have on their minds...they have a stick for cows on the one hand and an AK47 on the other" (EAfrica07). These groups in civil society may see few alternative options for themselves and may struggle to envision and work toward a better future. A participant described,

"It is a challenge, because you are dealing with human beings that are feeling hatred against them or fragmented society and feeling that they have no option or decision about the future for their children. They don't have anything to lose in the context of manmade disasters or armed conflict" (EAfrica07).

A disfigured civil society can be difficult to rehabilitate, and a nascent post-conflict civil society faces an uphill battle to build well-functioning systems. One participant remarked, "You have to restart from zero" (SAsia18).

It can be difficult to create a DRR community of practice where education systems have been absent for extended periods. Those with an education are often the first to flee conflict regions (SAsia18), and the remaining population may not have the baseline level of education and skills needed for even the most basic DRR engagement. When conflict is localized to a specific place, communities trained in DRR can lend support to communities recovering from conflict, but more widespread conflict can wipe out expertise and capacities in an entire region. DRR interventions may invest in training, but trainees may not be able to carry out planned activities due to lingering or renewed violence. In post-war Libya at the brink of relapse into 
armed conflict, one participant described, "We were training people [for DRR] on the third floor, and it was war on the first floor on the streets" (NAfrica01). The participant went on to explain that the trainees fled violence soon after the training concluded and lost touch with the project, which in turn lost its momentum.

\subsubsection{Dysfunctional government}

Conflict can render systems of governance absent, ineffective, or counterproductive in particular regions or entire jurisdictions. Poor functionality persists in post-conflict regions where institutions may be in a state of "destruction" and have little capacity to implement DRR projects (WAfrica17). Traction in DRR is elusive when every change in government leads to a loss in capacity. One participant reflected, "The one common denominator is the weakness or absence of the state in many places" (EAfrica/MAfrica04). Another participant commented,

"With so much protracted violence, it is very hard to see the government in action [in DRR]. Yes, they were there, but there was so much conflict and tension that a lot of times you couldn't see the impact" (EAfrica09).

Several conflict-affected countries feature multiple ruling governments with jurisdictions that may cut through cities or even overlap, and institutional incoherence can further blur and diffuse DRR responsibilities.

Governments in conflict regions may passively deprioritize DRR due to lack of knowledge, experience, and resources and focus their limited resources on other competing development priorities. A participant explained that the Government of Nepal does not understand the prevention principles of DRR:

"They [the Government of Nepal] think we have already one mandate that only during the disaster we have to support with relief. That is our obligation. That is our responsibility. But if we invest in preparedness and risk reduction, they think that this is a waste of money. They don't have [the] idea that [it is] part of sustainable development" (SAsia24).

Nepal's formal DRR has recently gained momentum with the development of new national policies on DRR, but the translation of these policies into practice has remained elusive (SAsia24). A participant working in post-war Sierra Leone similarly described, "Everything on paper is quite good, but when it comes to implementation, it [DRR] will not work" (WAfrica17). Most DRR policies and strategies developed in conflict-affected regions are incomplete and tend to favor high-profile physical infrastructure projects that win recognition for the politicians who erect them rather than meet actual needs (SAsia24). Political decision making drives DRR, and in conflict-affected regions, DRR is subject to conflicting interests. One participant explained,

"They prefer power to providing very simple [DRR] solutions to communities... Sometimes people do not know how to go beyond geopolitics and do not consider the human dimension...This behavior and selfishness is destroying efforts of development actors to either reduce the root causes of disaster or disaster itself" (MAfrica/WAfrica15). 
Authoritarian leaders in weak institutional contexts seldom see a political advantage to advancing DRR objectives. A participant in post-war Sierra Leone explained, "We have weak institutions but strong individuals [who] mislead people or cause people to hate or harm each other or cause pandemonium in the society using their influence and power" (WAfrica17). DRR can be used as a political tool, and governments may distribute DRR or disaster relief materials as favors to their constituents and political supporters and withhold these benefits from their adversaries. For example, a participant explained that the Government of South Sudan deliberately redirects international humanitarian and development aid away from rebelcontrolled areas (EAfrica11). Opposition groups also hold sway over DRR when they block or destroy DRR projects to put pressure on already-weakened government institutions or to undermine their political legitimacy.

Corruption and clientelism also undermine DRR. One participant explained that the government in post-war Nepal is characterized by "rampant corruption" and visionless development. The gross misallocation of funds has compromised progress toward DRR and other development projects such as clean drinking water, electrical production, and road infrastructure (SAsia23). The participant specified, "Money is not the problem. The problem with us in Nepal is poor management, mismanagement, and corruption" (SAsia23).

\subsubsection{Inconsistent external actors}

Certain regions may become too insecure or dangerous to implement DRR during specific periods of intense fighting, and DRR programming may be delayed or paused as implementing agencies wait for a gap in hostilities. However, inconsistent, untimely, or incomplete DRR may do little to reduce community disaster risks, and delays can destroy momentum. A participant described a DRR project that had to stall due to active conflict: "After two years, the energy, commitment, and resources have seriously decreased, and the support was very, very limited in comparison with what was planned initially" (MAfrica/WAfrica15).

Long-term DRR and programming aimed at disaster prevention may be discontinued altogether as activities shift toward short-term and limited disaster response, like air dropping food supplies. Projects may be shifted to other locations that feature similar natural hazard conditions but with little or no conflict-related violence. A participant explained,

"We had to ban that area and not implement the project there, though the zone was known to be prone to flooding. We could not provide support at all to that area...Sometimes Plan B is to move the project to a less prioritized zone instead of implementing the project in the zone that actually really needs that kind of project" (WAfrica15).

The participant specified that DRR services almost never reach the most vulnerable populations and described how challenging it is to grapple with the decision to implement or not:

“I is like a hell. They don't even know which type of disaster to deal with, you know? And, unfortunately in those zones, the development actors that we are, we simply leave the zone. We simply advise people not to go, though we know that people are exposed to all this challenge. So the issue is they are not only facing the double challenge and double disaster, which is natural and man-made, but they are also facing a third type of 
disaster, which is the hypocrisy of human beings. Because we want the conflict to end before we go. And I also agree with people who say, 'I will not go there to be killed.' So, it's quite complicated and a very difficult situation...But people are not going there, because people are killing people" (WAfrica15).

The most vulnerable populations end up bearing a larger share of disasters and disaster impacts than communities that benefit from consistent DRR programming (MAfrica13). Vulnerable populations are left behind in all aspects of development, including DRR, long after wars conclude, and the gap between the rich and resilient and the poor and vulnerable only widens over time (SAsia23; SAsia24). Even when DRR programs push forward with implementation in situations of extreme violence, there is little evidence of positive and sustainable impacts (EAfrica09). This may in part be due to the mismatch between standard protocols and realities on the ground. One participant explained, "At a certain point, you cannot really have $100 \%$ of the results you want, because not all the process has been followed in all the areas" (MAfrica/WAfrica15).

\subsubsection{Conflict increases disaster coping capacities}

A minority of participants identified ways that conflict supports coping capacities in indirect ways. Talking about conflict risks can open the door to talking about natural hazards and disaster risks (WAsia31) including in the post-conflict recovery process (NAfrica01), and this dialogue can be mobilized into action with the support of increased donor funding for conflict-affected regions (see Harrowell \& Özerdem, 2019 for a discussion of how post-conflict and post-disaster reconstruction processes have been broadly pursued separately despite an interest in linking them). Political interests in DRR do not have to be wholly benevolent to lead to societal benefits; post-conflict governments may be interested in pursuing DRR as a tool to increase political stability and the legitimacy of their regime (NAfrica01).

Alternatively, diminished government presence can paradoxically bring benefits to DRR. While a more established government can provide more uniform DRR coverage across a country, it can also come with increased bureaucracy, interference, and logistical restrictions for non-governmental and civil society DRR interventions (SAsia19). During conflicts, governmentimposed restrictions may loosen due to lowered capacity, and INGO/IGOs may be able to expand their programming (WAsia32) (see Marino \& Faas, 2020 for a discussion of how bureaucratic institutions, including INGO/IGOs, impose their power and agenda in disaster spaces). Decreased external presence can also create an incentive for certain communities to take more ownership over DRR, because they have to identify and pursue their own solutions. One participant narrated:

"Communities have a lot more creativity and willingness and ingenuity around reducing those risks for some of the populations. So you have a lot more engagement and thinking through and a lot less dependency on government to intervene or support" (EAfrica07).

Yet, not all conflict-affected communities have the baseline human and financial resources to initiate or complete ambitious projects independently, and communities with significant intracommunity conflict may be especially unlikely to cooperate on DRR. 


\section{Discussion}

The research findings suggest that understanding disaster risks in conflict-affected regions has previously been incomplete. Across broad geographies and conflict typologies, conflict affects disaster risk creation through a suite of pathways and mechanisms. Conflict contributes to disaster vulnerabilities, which is in line with previous research (e.g., Wisner et al., 2004; Peters, 2018), but conflict also percolates into disaster risks through diverse and reinforcing pathways (see Figure 2): conflict magnifies existing hazards and creates new hazards, increases exposure, creates and increases vulnerabilities, and decreases and increases coping capacities. Additionally, conflict acts as a disaster multiplier, increasing both the likelihood of disaster and the magnitude of disaster impacts, and it can simultaneously function as the context. Conflict may follow multiple mutually reinforcing pathways to disaster risk creation at a given time and place, and these pathways may shift throughout the progression of a conflict. Certain conflict themes may influence more than one component of disaster risk (for example, forced displacement can lead to increased exposure and increased vulnerability; see Table 2), and a given conflict-related disaster risk driver may lead to cascading disaster risk drivers (e.g., food insecurity driven by loss of livelihoods may drive unsustainable agricultural practices, thus contributing to both vulnerability and hazard creation).

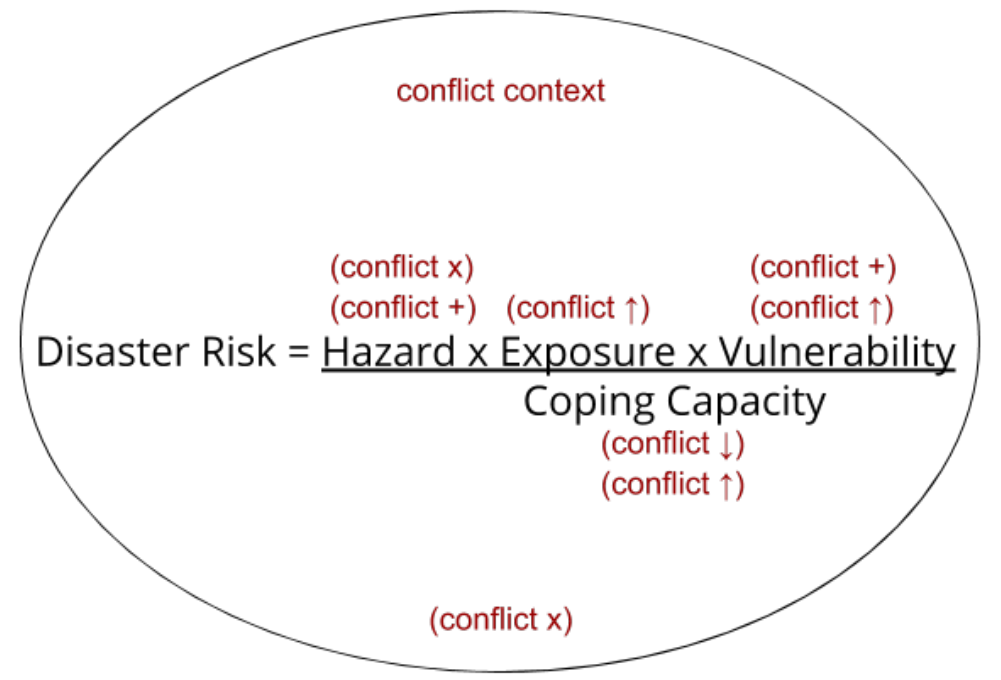

Figure 2. Conflict influences disaster risk through multiple channels. x indicates "multiplies," + indicates "adds," $\uparrow$ indicates "increases," and $\downarrow$ indicates "decreases." Conflict is the context; conflict is a disaster multiplier; conflict magnifies existing hazards and creates new hazards; conflict increases exposure; conflict creates and increases vulnerabilities; conflict decreases and increases coping capacities. 
Table 2. Linkages between conflict themes, conflict-related disaster risk drivers, and components of disaster risk.

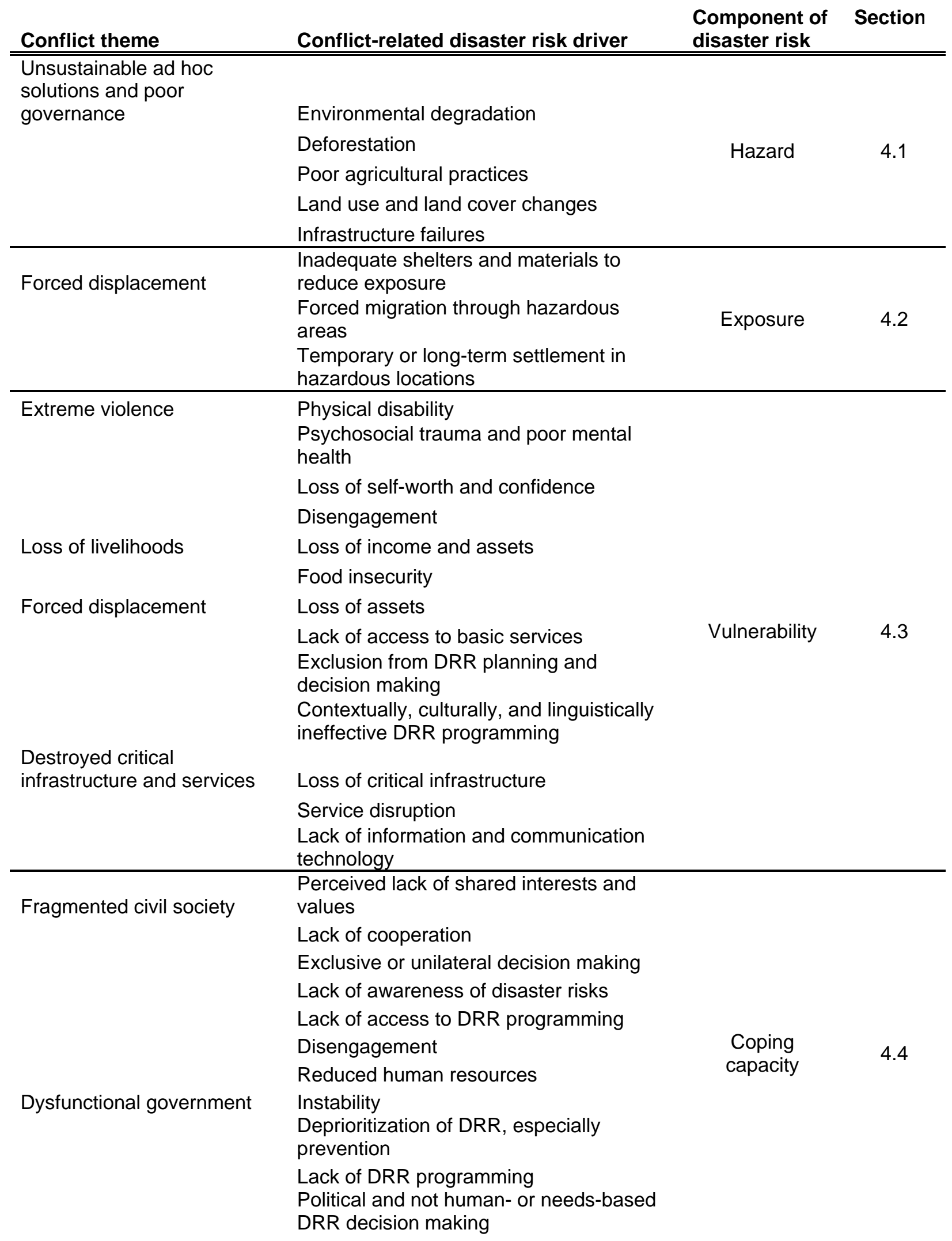




$\begin{array}{ll} & \text { Magnification of societal fragmentation } \\ \text { and division } & \\ \text { Poor or corrupt DRR management } & \text { Delayed or discontinued long-term and } \\ \text { prevention-focused DRR programming } \\ \text { Limited to short-term and limited disaster } \\ \text { response } \\ \text { Neglect of populations most affected by } \\ \text { active conflict } \\ \text { Widening of gaps between socioeconomic } \\ \text { groups }\end{array}$

While the vast majority of interview results points to how conflict leads to increased disaster risks, there is limited evidence that conflict can increase local coping capacities in certain ways. Coping capacities are affected positively and negatively by external forms of support which can wax and wane due to conflict. Heijmans et al. (2009) argued that local needs and capacities are central to effective DRR, but local systems of governance that struggle to plan and manage DRR may also benefit from external sources of support to build their capacity (Manyena, 2006). Conflict can attract an influx of outside resources, though there tends to be very little investment in DRR in conflict-affected regions (Peters \& Budimir, 2016), and DRR may remain the agenda of international actors rather than be championed by state government or local communities (Mena \& Hilhorst, 2020). Conversely, DRR may thrive when external forms of support retreat, and local populations gain the space to independently pursue their own solutions. These findings illustrate that the pathways leading from conflict to disaster risks are not linear or consistent from place to place, and conflict can both increase and decrease coping capacities.

Disaster risk creation occurs through various channels (i.e., hazards, exposure, vulnerabilities, and coping capacities) at multiple temporal and institutional scales (see Figure 3). Influences at one scale may stymie, reinforce, or magnify those at another scale, and crossscale interactions shape the disaster risks that emerge and take root. For example, disaster governance systems may become driven by security concerns in conflict-affected regions (Field \& Kelman, 2018) or avoid areas affected by conflict (Desportes et al., 2019) and may not provide adequate and appropriate services to conflict-affected populations. The gap between needs and services may drive individuals and households to pursue unsustainable solutions that create or magnify natural hazards. This finding mirrors previous research by Conca and Wallace (2009) that conflicts can lead to environmental degradation in part through unsustainable choices at small scales to meet immediate needs in the absence of other viable options. As conflict progresses, disaster risks may shift, and progressive stages of conflict may carry the legacies of earlier stages of conflict on disaster risks. For example, a post-conflict region may experience the lingering impacts of extreme violence and destroyed livelihoods, and these legacy effects may be joined by new challenges. 


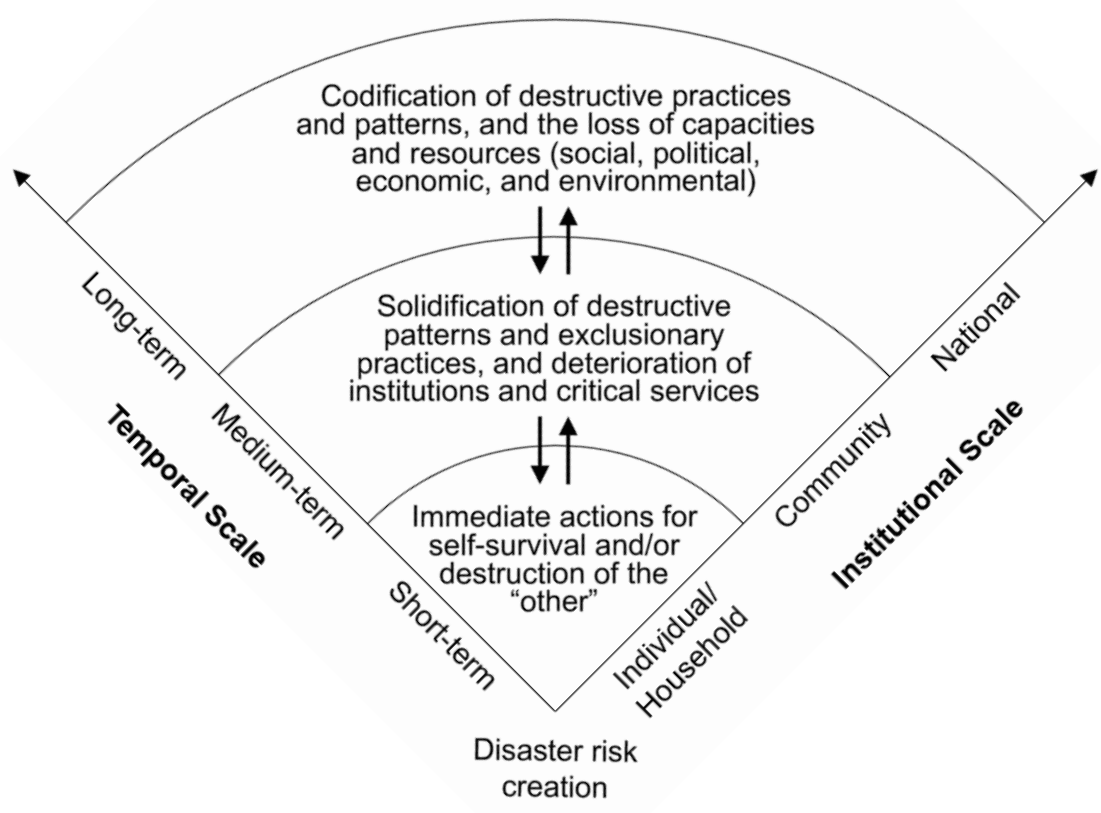

Figure 3. Interacting temporal and institutional scales of disaster risk creation. Systems of disaster risk are further perpetuated by diverse international influences, including donor control of resource flows, the primacy of international actors in decision making, international investment in resource extractive industries, and other means of advancing international interests.

The research findings have the potential to bear on strategic approaches to DRR in conflict-affected regions. As the findings have demonstrated, disaster risks are elevated in conflict-affected regions and within conflict-affected populations, including in post-conflict regions and areas that host forcibly displaced people. Actors implementing DRR cannot neglect individuals, households, communities, and countries affected by conflict either through direct avoidance or by providing interventions ill-suited to specific conflict conditions. Strategies to "work around" or ignore conflict, while common, will not effectively reduce disaster risks. DRR must "work on" conflict to address the root causes of disaster. The other reason that conflict should not be ignored or stifled is that conflict has the potential to be constructive and lead to improved relationships and societal benefits (Deutsch, 1994; Kriesberg, 2007). Constructive conflict thus also has the potential to help ameliorate disaster risks if engaged with strategically (Peters \& Kelman, 2020).

Particularly when facing sudden and extreme conflict conditions, participants expressed that they cannot rely on existing best practices and standard procedures for DRR. This points to 
the need for robust strategies and approaches to DRR in conflict-affected regions that enable nimble and effective action in the pursuit of sustainable solutions. The development of adaptable strategies and not a singular strategy is paramount. Conflict and disaster profiles are unique, because they emerge from societal histories and patterns. Even in the same physical spaces, conflict and disaster combinations affect different people differently. Conflict-affected regions or populations may be poorly served when they are homogenously categorized and their distinct challenges and opportunities are obscured. This adds another layer to recent research on intersectional disaster vulnerabilities. Individuals may simultaneously belong to multiple groups or identities, leading to complex patterns of vulnerabilities (Vickery, 2018), and the experiences, needs, and priorities of individuals may not be adequately captured when DRR aggregates "vulnerability" into a single category (Chaplin et al., 2019). Even the most marginalized and vulnerable people are not just victims of circumstance, but they also possess capacities (Gaillard, 2019) and practice individual and collective coping strategies in the face of disaster (Zaman et al., 2020). DRR policy would benefit from developing diverse guidance that corresponds with these nuances and could be tailored to specific disaster, conflict, and broader societal conditions. This should also take into consideration the various political actors beyond the state, like rebel groups and informal institutions, that may positively and negatively affect DRR efforts (Walch, 2018). The voices of DRR experts working at the ground level as well as affected communities themselves must feature prominently in these discussions and policy decisions. Alternative forms of disaster governance drawing from rights-based and ownership approaches may strengthen accountability for DRR under the Sendai Framework (Raju \& da Costa, 2018).

This research contributes to literature bringing to light the political and conflict-related causes of disaster (Lewis \& Kelman, 2012; Peters, Holloway, \& Peters, 2019; Siddiqi, 2018) and literature examining the complex relationships between disasters, conflicts, and peace (Olson \& Gawronski, 2017; Peters \& Kelman, 2020; von Uexkull et al., 2016). The insights provided by this article strengthen the case for DRR to address conflict directly, both to reduce disaster risks and also potentially to reduce additional post-disaster conflict risks. Disasters have the potential to create, magnify, or perpetuate conflicts, but disasters can also serve as "critical junctures" (Olson \& Gawronski, 2003; Pelling \& Dill, 2006; 2010) and opportunities to promote diplomacy and peace (Kelman, 2012).

This research focuses on how conflict influences natural hazard-related disaster risks and not how conflicts can be conceptualized as anthropogenic hazards or disasters. The research findings are limited to the experiences and perspectives of international and national non-governmental organizations and multilateral organizations, and they do not capture the perspectives of other actors operating in the same spaces, including governments and informal local institutions. The synthesized findings represent a breadth of experiences rather than depth into any given context. Future research should build on the understanding of conflict as an intrinsic part of disaster risk creation and investigate strategies and practical approaches that DRR employs in conflict-affected regions. The identification of entry points and frameworks to make progress on addressing the conflict-related root causes of disaster while also preventing, mitigating, or transforming add-on conflict risks would be particularly beneficial. 


\section{Conclusion}

This research empirically explored how conflict features into disaster risk creation by drawing from the experiential knowledge of 32 DRR experts across 25 countries in the Middle East, South Asia, and Africa. The key findings are that 1) conflict is a driver of disaster risks in conflict-affected regions, 2) conflict follows pathways to disaster risk creation that are not limited to vulnerabilities, and 3) these conflict influences occur at multiple temporal and institutional scales. While the direct impacts of a conflict may be concentrated at a specific institutional scale, the indirect impacts may filter through other institutional scales and extend into short-, medium-, and long-term time horizons. This research strengthens the case that disaster-conflict scholarship should reconsider the multifaceted roles that conflict plays in the creation and reinforcement of disaster risks. Conflict cannot be outside the purview of DRR where disaster risks are embedded within conflict; DRR must directly address conflict while working on the causal factors of disaster to yield meaningful progress in reducing disaster losses and impacts. This research contributes to a deeper and more nuanced knowledge of disaster risks in conflictaffected regions and may lead to more targeted entry points and strategies for DRR to prevent, mitigate, prepare for, and respond to disasters in some of the most disaster- and conflict-prone regions of the world.

Acknowledgements

I am indebted to the DRR experts who participated in this study and shared their perspectives with me. I am grateful to Aaron T. Wolf for his comments on early manuscript drafts and to Jamon Van Den Hoek for his comments on manuscript drafts and assistance in making article figures.

Funding

This research did not receive any specific grant from funding agencies in the public, commercial, or not-for-profit sectors.

\section{References}

Alexander, D. E. (2020). How to manage an emergency or disaster. Dunedin Academic Press.

Asfour, O. S. (2019). Learning from the past: Temporary housing criteria in conflict areas with reference to thermal comfort. International Journal of Disaster Risk Reduction, 38, 101206.

Azar, E., Jureidini, P., \& McLaurin, R. (1978). Protracted social conflict: Theory and practice in the Middle East. Journal of Palestine Studies, 8(1), 41-60.

Bagley, J. E., Desai, A. R., Harding, K. J., Snyder, P. K., \& Foley, J. A. (2014). Drought and deforestation: Has land cover change influenced recent precipitation extremes in the Amazon?. Journal of Climate, 27, 345-361.

Ball, N. (1975). The myth of the natural disaster. The Ecologist, 5(10), 368-369.

Bradshaw, C. J. A., Sodhi, N. S., Peh, K. S. H., \& Brook, B. W. (2007). Global evidence that 
deforestation amplifies flood risk and severity in the developing world. Global Change Biology, 13(11), 2379-2395.

Baumann, M., \& Kuemmerle, T. (2016). The impacts of warfare and armed conflict on land systems. Journal of Land Use Science, 11(6), 672-688.

Bernard, H. R. (2011). Research methods in anthropology: Qualitative and quantitative approaches (5th edition). AltaMira Press.

Bertaux, D. (1981). From the life-history approach to the transformation of sociological practice. In D. Bertaux (Ed.), Biography and society: The life history approach in the social sciences (pp. 29-45). Sage.

Birt, L., Scott, S., Cavers, D., Campbell, C., \& Walter, F. (2016). Member checking: A tool to enhance trustworthiness or merely a nod to validation?. Qualitative Health Research, 26(13), 1802-1811.

Black, R., Arnell, N. W., Adger, W. N., Thomas, D., \& Geddes, A. (2013). Migration, immobility and displacement outcomes following extreme events. Environmental Science \& Policy, 27(S1), S32-S43.

Branch, A. (2018). From disaster to devastation: Drought as war in northern Uganda. Disasters, 42(S2), S306-S327.

Brewer, J., \& Hayes, B. C. (2011). Post-conflict societies and the social sciences: A review. Contemporary Social Science, 6(1), 5-18.

Brzoska, M. (2018). Weather extremes, disasters, and collective violence: Conditions, mechanisms, and disaster-related policies in recent research. Current Climate Change Reports, 4, 320-329.

Cammet, M. (2006). Political ethnography in deeply divided societies. Qualitative Methods, 4(2), 15-18.

Carment, D., Samy, Y., Prest, S. (2008). State fragility and implications for aid allocation: An empirical analysis. Conflict Management and Peace Science, 25, 349-373.

Chaplin, D., Twigg, J., \& Lovell, E. (2019). Intersectional approaches to vulnerability reduction and resilience-building. BRACED Resilience Intel, 12. Retrieved March 3, 2020, from https://www.odi.org/sites/odi.org.uk/files/resource-documents/12651.pdf

Conca, K., \& Wallace, J. (2009). Environment and peacebuilding in war-torn societies: Lessons from the UN Environment Programme's experience with postconflict assessment. Global Governance, 15(4), 485-504.

DasGupta, R., \& Shaw, R. (2017). Disaster risk reduction: A critical approach. In I. Kelman, J. Mercer, \& J. C. Gaillard (Eds.), The Routledge handbook of disaster risk reduction including climate change adaptation (pp. 12-23). Routledge.

Desportes, I., Mandefro, H., \& Hilhorst, D. (2019). The humanitarian theatre: Drought response 
during Ethiopia's low-intensity conflict of 2016. The Journal of Modern African Studies, 57(1), 31-59.

Desportes, I., \& Hilhorst, D. (2020). Disaster governance in conflict-affected authoritarian contexts: The cases of Ethiopia, Myanmar, and Zimbabwe. Politics and Governance, 8(4), 343-354.

Deutsch, M. (1994). Constructive conflict resolution: Principles, training, and research. Journal of Social Issues, 50(1), 13-32.

de Waal, A. (2018). Mass starvation: The history and future of famine. Polity Press.

Drury, A. C., \& Olson, R. S. (1998). Disasters and political unrest: An empirical investigation. Journal of Contingencies and Crisis Management, 6(3), 153-161.

Eastin, J. (2016). Fuel to the fire: Natural disasters and the duration of civil conflict. International Interactions, 42(2), 322-349.

Falk, R. A. (1973). Environmental Warfare and Ecocide - Facts, Appraisal, and Proposals. Bulletin of Peace Proposals, 4(1), 80-96.

Field, J., \& Kelman, I. (2018). The impact on disaster governance of the intersection of environmental hazards, border conflict and disaster responses in Ladakh, India. International Journal of Disaster Risk Reduction, 31, 650-658.

Gaillard, J. C. (2018). Disaster studies inside out. Disasters, 43(S1), S7-S17.

Gawande, K., Kapur, D., \& Satyanath, S. (2017). Renewable natural resource shocks and conflict intensity: Findings from India's ongoing Maoist insurgency. Journal of Conflict Resolution 61(1), 140-172.

Glade, T. (2003). Landslide occurrence as a response to land use change: A review of evidence from New Zealand. CATENA, 51(3-4), 297-314.

Goodhand, J. (2000). Research in conflict zones: Ethics and accountability. Forced Migration Review, 8(4), 12-16.

Harrowell, E., \& Özerdem, A. (2019). Understanding the dilemmas of integrating post-disaster and post-conflict reconstruction initiatives: Evidence from Nepal, Sri Lanka and Indonesia. International Journal of Disaster Risk Reduction, 36, 101092.

Hartmann, B. (2010). Rethinking climate refugees and climate conflict: Rhetoric, reality and the politics of policy discourse. Journal of International Development, 22, 233-246.

Harvey, L. (2015). Beyond member-checking: A dialogic approach to the research interview. International Journal of Research \& Method in Education, 38(1), 23-38.

Heijmans, A., Okechukwu, I., Schuller tot Peursum, A., \& Skarubowiz, R. (2009). A grassroots 
perspective on risks stemming from disasters and conflict. Humanitarian Exchange, 44, 34-35.

Hendrix, C. S., \& Salehyan, I. (2012). Climate change, rainfall, and social conflict in Africa. Journal of Peace Research, 49(1), 35-50.

Hewitt, K. (ed.). (1983). Interpretations of calamity from the viewpoint of human ecology. Allen \& Unwin.

Hough, P. (2016). Trying to end the war on the world: The campaign to proscribe military ecocide. Global Security: Health, Science and Policy, 1(1), 10-22.

Ide, T., Brzoska, M., Donges, J. F., \& Schleussner, C. F. (2020). Multi-method evidence for when and how climate-related disasters contribute to armed conflict risk. Global Environmental Change, 62, 102063.

Keller, E. (1992). Drought, war, and the politics of famine in Ethiopia and Eritrea. The Journal of Modern African Studies, 30(4), 609-624.

Kelman, I. (2012). Disaster diplomacy: How disasters affect peace and conflict. Routledge.

Kelman, I. (2018). Lost for words amongst disaster risk science vocabulary?. International Journal of Disaster Risk Science, 9, 281-291.

Kriesberg, L. (2007). Constructive conflicts: From escalation to resolution ( $3^{\text {rd }}$ edition). Rowman \& Littlefield.

Lemma, H. (1985). The politics of famine in Ethiopia. Review of African Political Economy, 12(33), 44-58.

Lewis, J. (1988). On the line: An open letter in response to 'Confronting natural disasters, an international decade for natural hazard reduction'. Natural Hazards Observer, 7(4), 4.

Lewis, J. (1999). Development in disaster-prone places: Studies of vulnerability. Intermediate Technology Publications.

Lewis, J., \& Kelman, I. (2012). The good, the bad and the ugly: Disaster Risk Reduction (DRR) versus Disaster Risk Creation (DRC). Public Library of Science (PLoS) Currents: Disasters, 21 June. Retrieved February 7, 2020, from https://www.ncbi.nlm.nih.gov/pmc/articles/PMC3423310/

Linke, A. M., Witmer, F. D. W., O'Loughlin, J., McCabe, J. T., \& Tir, J. (2018). Drought, local institutional contexts, and support for violence in Kenya. Journal of Conflict Resolution, 62(7), 1544-1578.

Manyena, S. B. (2006). Rural local authorities and disaster resilience in Zimbabwe. Disaster Prevention and Management, 15(5), 810-820. 
Marino, E. K., \& Faas, A. J. (2020). Is vulnerability an outdated concept? After subjects and spaces. Annals of Anthropological Practice.

Marktanner, M., Mienie, E., \& Noiset, L. (2015). From armed conflict to disaster vulnerability. Disaster Prevention and Management, 24(1), 53-69.

Maystadt, J. F., Mueller, V., Van Den Hoek, J., van Weezel, S. (2020). Vegetation changes attributable to refugees in Africa coincide with agricultural deforestation. Environmental Research Letters, 15(4), 044008.

Mealer, M., \& Jones, J. (2014). Methodological and ethical issues related to qualitative telephone interviews on sensitive topics. Nurse Researcher, 21(4), 32-37.

Mena, R., \& Hilhorst, D. (2020). The (im)possibilities of disaster risk reduction in the context of high-intensity conflict: The case of Afghanistan. Environmental Hazards.

Miles, M., \& Huberman, A. M. (1994). Qualitative data analysis: An expanded sourcebook ( $2^{\text {nd }}$ edition). Sage Publications.

Mohanty, A., Hussain, M., Mishra, M., Kattel, D. B., \& Pal, I. (2019). Exploring community resilience and early warning solution for flash floods, debris flow and landslides in conflict prone villages of Badakhshan, Afghanistan. International Journal of Disaster Risk Reduction, 33, 5-15.

Murillo-Sandoval, P. J., Van Dexter, K., Van Den Hoek, J., Wrathall, D., \& Kennedy, R. (2020). The end of gunpoint conservation: Forest disturbance after the Colombian peace agreement. Environmental Research Letters, 15(3), 034033.

Nel, P., \& Righarts, M. (2008). Natural disasters and the risk of violent civil conflict. International Studies Quarterly, 52(1), 159-185.

OCHA (United Nations Office for the Coordination of Humanitarian Affairs). (2018). Afghanistan: Humanitarian needs overview (2019). UN OCHA. Retrieved June 30, 2020, from https://www.humanitarianresponse.info/en/operations/afghanistan/document/afghanistan -humanitarian-needs-overview-2019

OCHA (United Nations Office for the Coordination of Humanitarian Affairs). (2020). South Sudan: Situation report. UN OCHA. Retrieved July 17, 2020, from https://reports.unocha.org/en/country/south-sudan/

O'Keefe, P., Westgate, K., \& Wisner, B. (1976). Taking the naturalness out of natural disasters. Nature, 260, 566-567.

OECD (Organisation for Economic Cooperation and Development). (2018). States of Fragility 2018. OECD Publishing.

Olson, R. S., \& Gawronski, V. (2003). Disasters as critical junctures? Mangua, Nicaragua 1972 and Mexico City 1985. International Journal of Mass Emergencies and Disasters, 21(1), 5-35. 
Olson, R. S., \& Gawronski, V. T. (2017). Violent conflict and disaster risk reduction including climate change adaptation. In I. Kelman, J. Mercer, \& J. C. Gaillard (Eds.), The Routledge handbook of disaster risk reduction including climate change adaptation (pp. 150-160). Routledge.

Pelling, M., \& Dill, K. (2006). 'Natural' disasters as catalysts of political action. Chatham House.

Pelling, M., \& Dill, K. (2010). Disaster politics: Tipping points for change in the adaptation of sociopolitical regimes. Progress in Human Geography, 34(1), 21-37.

Peluso, N., \& Vandergeest, P. (2011). Taking the jungle out of the forest. In R. Peat, P. Robbins, \& M. Watts (Eds.), Global political ecology (pp. 252-284). Routledge.

Peters, K. (2018). Accelerating Sendai Framework implementation in Asia: Disaster risk reduction in contexts of violence, conflict and fragility. Overseas Development Institute.

Peters, K. (2019). Disaster risk reduction in conflict contexts: An agenda for action. Overseas Development Institute.

Peters, K., \& Budimir, M. (2016). When disasters and conflicts collide: Facts and figures. Overseas Development Institute.

Peters, K., Eltinay, N., \& Holloway, K. (2019). Disaster risk reduction, urban informality and a 'fragile peace'. Overseas Development Institute.

Peters, K., Holloway, K., \& Peters, L. E. R. (2019). Disaster risk reduction in conflict contexts: The state of the evidence. Overseas Development Institute.

Peters, K., Peters, L. E. R., Twigg, J., \& Walch, C. (2019). Disaster risk reduction strategies: Navigating conflict contexts. Overseas Development Institute.

Peters, L. E. R., \& Kelman, I. (2020). A critiquing overview of intersections of disaster, conflict, and peace research. International Journal of Disaster Risk Science.

Pettersson, T., \& Eck, K. (2018). Organized violence, 1989-2017. Journal of Peace Research, 55(4), 535-547.

Raju, E., \& da Costa, K. (2018). Governance in the Sendai: A way ahead? Disaster Prevention and Management, 27(3), 278-291.

Sarker, A. A., \& Rashid, A. K. M. M. (2013). Landslide and flashflood in Bangladesh. In R. Shaw, F. Mallick, \& A. Islam (Eds.), Disaster risk reduction approaches in Bangladesh. Disaster Risk Reduction (Methods, Approaches and Practices). Springer.

Schuld, M. (2013). The prevalence of violence in post-conflict societies: A case study of 
Kwazulu-Natal, South Africa. Journal of Peacebuilding \& Development, 8(1), 60-73.

Schwartz, J., \& Halkyard, P. (2006). Post-conflict infrastructure: Trends in aid and investment flows. Viewpoint: Public Policy for the Private Sector. Note No. 305. World Bank. Retrieved July 16, 2020, from https://openknowledge.worldbank.org/handle/10986/11187

Siddiqi, A. (2018). Disasters in conflict areas: Finding the politics. Disasters, 42(S2), S161-S172.

Siddiqi, A., Peters, K., \& Zulver, J. (2019). 'Doble afectacion': Living with disasters and conflict in Colombia. Overseas Development Institute.

Tiranti, D. (1977). The un-natural disasters. The New Internationalist, 53, 5-6.

UNDRR (United Nations Office for Disaster Risk Reduction) \& ISC (International Science Council). (2020). Hazard definition \& classification review. Retrieved January 6, 2020, from https://www.undrr.org/publication/hazard-definition-and-classification-review

UNFPA (United Nations Population Fund). (2015). Shelter from the storm: A transformative agenda for women and girls in a crisis-prone world. The State of World Population 2015. United Nations. Retrieved July 16, 2020, from https://www.unfpa.org/sites/default/files/sowp/downloads/State_of_World_Population_20 15_EN.pdf

UNGA (United Nations General Assembly). (2017). Report of the open-ended intergovernmental expert working group on indicators and terminology relating to disaster risk reduction. Retrieved July 16, 2020, from https://www.preventionweb.net/files/50683_oiewgreportenglish.pdf

UNICEF Yemen (United Nations International Children's Fund Yemen). (2015). UNICEF Yemen crisis situation report. United Nations. Retrieved July 16, 2020, from https://www.unicef.org/appeals/files/UNICEF_Yemen_Humanitarian_SitRep_17_Nov_20 15.pdf

UNISDR (United Nations International Strategy for Disaster Reduction). (2015). Sendai framework for disaster risk reduction 2015-2030. United Nations.

Vickery, J. (2018). Using an intersectional approach to advance understanding of homeless persons' vulnerability to disaster. Environmental Sociology, 4(1), 136-147.

von Uexkull, N., Croicu, M., Fjelde, H., \& Buhaug, H. (2016). Civil conflict sensitivity to growing-season drought. Proceedings of the National Academy of Sciences, 113(44), 12391-12396.

Walch, C. (2018). Disaster risk reduction amidst armed conflict: Informal institutions, rebel groups, and wartime political orders. Disasters, 42(S2), S239-S264.

Watts, M. J. (1983). Silent violence: Food, famine and peasantry in northern Nigeria. University of California Press. 
Watts, M. J. (2013). Silent violence: Food, famine, and peasantry in northern Nigeria: With a new introduction (Geographies of justice and social transformation). University of Georgia Press.

Willms, D. G., Best, J. A., Taylor, D. W., Gilbert, J. R., Wilson, D. M. C., Lindsay, E. A., \& Singer, J. (1990). A systematic approach for using qualitative methods in primary prevention research. Medical Anthropology Quarterly, 4(4), 391-409.

Wisner, B., Blaikie, P., Cannon, T., \& Davis, I. (2004). At risk: Natural hazards, people's vulnerability and disasters ( $2^{\text {nd }}$ edition). Routledge.

Zaman, S., Sammonds, P., Ahmed, B., \& Rahman, T. (2020). Disaster risk reduction in conflict contexts: Lessons learned from the lived experiences of Rohingya refugees in Cox's Bazar, Bangladesh. International Journal of Disaster Risk Reduction, 50, 101694.

Zierler, D. (2011). The invention of ecocide: Agent Orange, Vietnam, and the scientists who changed the way we think about the environment. University of Georgia Press. 
Appendix A. Description of interview participants.

\begin{tabular}{|c|c|c|c|c|c|c|}
\hline $\begin{array}{l}\text { Interview } \\
\text { Region }\end{array}$ & $\begin{array}{l}\text { Interview } \\
\#\end{array}$ & Country & $\begin{array}{l}\text { Relevant } \\
\text { In-Country } \\
\text { DRR } \\
\text { Experience }\end{array}$ & Type of Organization & $\begin{array}{l}\text { Position Title at Time } \\
\text { of Interview }\end{array}$ & Sex \\
\hline \multirow{3}{*}{$\begin{array}{l}\text { Northern } \\
\text { Africa } \\
\text { (NAfrica) }\end{array}$} & 01 & $\begin{array}{l}\text { Egypt; } \\
\text { Libya }\end{array}$ & $2008-2016$ & Multilateral Organization & $\begin{array}{l}\text { Education Program } \\
\text { Specialist }\end{array}$ & M \\
\hline & 02 & Libya & 2018 & $\begin{array}{l}\text { Multilateral } \\
\text { Organization/International } \\
\text { Non-Governmental } \\
\text { Organization }\end{array}$ & $\begin{array}{l}\text { Organizational } \\
\text { Development Delegate }\end{array}$ & M \\
\hline & 03 & Sudan & 2016-2018 & Multilateral Organization & $\begin{array}{l}\text { Director of Urban } \\
\text { Planning and } \\
\text { Sustainable } \\
\text { Development }\end{array}$ & $\mathrm{F}$ \\
\hline \multirow{9}{*}{$\begin{array}{l}\text { Eastern } \\
\text { Africa } \\
\text { (EAfrica) }\end{array}$} & 04 & $\begin{array}{l}\text { Burundi; } \\
\text { Zimbabwe }\end{array}$ & 2017-2019 & $\begin{array}{l}\text { International Non- } \\
\text { Governmental } \\
\text { Organization }\end{array}$ & $\begin{array}{l}\text { Regional Emergency } \\
\text { Manager for Central \& } \\
\text { Southern Africa }\end{array}$ & M \\
\hline & 05 & Ethiopia & 2008-2019 & $\begin{array}{l}\text { International Non- } \\
\text { Governmental } \\
\text { Organization }\end{array}$ & Executive Director & M \\
\hline & 06 & $\begin{array}{l}\text { Ethiopia; } \\
\text { Kenya }\end{array}$ & 2010-2016 & $\begin{array}{l}\text { International Non- } \\
\text { Governmental } \\
\text { Organization }\end{array}$ & Consultant & M \\
\hline & 07 & Kenya & 2018 & $\begin{array}{l}\text { International Non- } \\
\text { Governmental } \\
\text { Organization }\end{array}$ & $\begin{array}{l}\text { Program Coordinator } \\
\text { for Inclusive } \\
\text { Humanitarian Action }\end{array}$ & M \\
\hline & 08 & Kenya & 2014-2015 & $\begin{array}{l}\text { International Non- } \\
\text { Governmental } \\
\text { Organization }\end{array}$ & $\begin{array}{l}\text { Global Climate Justice } \\
\text { Coordinator }\end{array}$ & M \\
\hline & 09 & $\begin{array}{l}\text { Kenya; } \\
\text { Somalia }\end{array}$ & $2008-2010$ & International Network & $\begin{array}{l}\text { East African Regional } \\
\text { Development } \\
\text { Coordinator }\end{array}$ & $\mathrm{F}$ \\
\hline & 10 & $\begin{array}{l}\text { Kenya; } \\
\text { Somalia; } \\
\text { South } \\
\text { Sudan }\end{array}$ & $2012-2018$ & $\begin{array}{l}\text { International Non- } \\
\text { Governmental } \\
\text { Organization }\end{array}$ & $\begin{array}{l}\text { Training of Trainer } \\
\text { Advisor East \& } \\
\text { Southern Africa }\end{array}$ & $\mathrm{F}$ \\
\hline & 11 & $\begin{array}{l}\text { South } \\
\text { Sudan }\end{array}$ & 2012-2019 & $\begin{array}{l}\text { International Non- } \\
\text { Governmental } \\
\text { Organization }\end{array}$ & $\begin{array}{l}\text { Advisor of Resource } \\
\text { Governance }\end{array}$ & M \\
\hline & 12 & $\begin{array}{l}\text { South } \\
\text { Sudan }\end{array}$ & 2008-2019 & $\begin{array}{l}\text { International Non- } \\
\text { Governmental } \\
\text { Organization }\end{array}$ & Forum Coordinator & M \\
\hline
\end{tabular}




\begin{tabular}{|c|c|c|c|c|c|c|}
\hline \multirow{4}{*}{$\begin{array}{l}\text { Middle } \\
\text { Africa } \\
\text { (MAfrica) }\end{array}$} & 04 & $\begin{array}{l}\text { Democratic } \\
\text { Republic of } \\
\text { the Congo }\end{array}$ & 2017-2019 & $\begin{array}{l}\text { International Non- } \\
\text { Governmental } \\
\text { Organization }\end{array}$ & $\begin{array}{l}\text { Regional Emergency } \\
\text { Manager for Central \& } \\
\text { Southern Africa }\end{array}$ & M \\
\hline & 13 & Cameroon & $2005-2019$ & $\begin{array}{l}\text { National Non- } \\
\text { Governmental } \\
\text { Organization }\end{array}$ & Coordinator & M \\
\hline & 14 & Cameroon & 2017-2019 & $\begin{array}{l}\text { National Non- } \\
\text { Governmental } \\
\text { Organization }\end{array}$ & $\begin{array}{l}\text { Co-Founder and } \\
\text { Coordinator }\end{array}$ & $\mathrm{F}$ \\
\hline & 15 & $\begin{array}{l}\text { Cameroon; } \\
\text { Chad }\end{array}$ & 2016-2019 & International Network & $\begin{array}{l}\text { Western \& Central } \\
\text { African Regional } \\
\text { Development } \\
\text { Coordinator }\end{array}$ & M \\
\hline \multirow{3}{*}{$\begin{array}{l}\text { Western } \\
\text { Africa } \\
\text { (WAfrica) }\end{array}$} & 15 & $\begin{array}{l}\text { Niger; } \\
\text { Nigeria; } \\
\text { Senegal }\end{array}$ & 2016-2019 & International Network & $\begin{array}{l}\text { Western \& Central } \\
\text { African Regional } \\
\text { Development } \\
\text { Coordinator }\end{array}$ & M \\
\hline & 16 & Liberia & $2015-2019$ & $\begin{array}{l}\text { Multilateral } \\
\text { Organization/International } \\
\text { Non-Governmental } \\
\text { Organization }\end{array}$ & $\begin{array}{l}\text { Acting Head of Country } \\
\text { Office; Disaster } \\
\text { Management Delegate }\end{array}$ & M \\
\hline & 17 & $\begin{array}{l}\text { Sierra } \\
\text { Leone }\end{array}$ & 2018 & $\begin{array}{l}\text { International Non- } \\
\text { Governmental } \\
\text { Organization }\end{array}$ & $\begin{array}{l}\text { Resilience Programme } \\
\text { Manager }\end{array}$ & M \\
\hline \multirow{6}{*}{$\begin{array}{l}\text { Southern } \\
\text { Asia } \\
\text { (SAsia) }\end{array}$} & 18 & Afghanistan & 2008-2019 & $\begin{array}{l}\text { International Non- } \\
\text { Governmental } \\
\text { Organization }\end{array}$ & Associate Director & M \\
\hline & 19 & Afghanistan & $1995-2018$ & $\begin{array}{l}\text { International Non- } \\
\text { Governmental } \\
\text { Organization }\end{array}$ & Retired & M \\
\hline & 20 & Bangladesh & 2018-2019 & $\begin{array}{l}\text { National Non- } \\
\text { Governmental } \\
\text { Organization }\end{array}$ & $\begin{array}{l}\text { Program Head for } \\
\text { Disaster and } \\
\text { Humanitarian } \\
\text { Management }\end{array}$ & M \\
\hline & 21 & Bangladesh & 2014-2019 & $\begin{array}{l}\text { International Non- } \\
\text { Governmental } \\
\text { Organization }\end{array}$ & DRR Officer & M \\
\hline & 22 & India & 2014-2019 & $\begin{array}{l}\text { National Non- } \\
\text { Governmental } \\
\text { Organization }\end{array}$ & Consultant & M \\
\hline & 23 & Nepal & $1998-2019$ & $\begin{array}{l}\text { National Non- } \\
\text { Governmental } \\
\text { Organization }\end{array}$ & President & M \\
\hline
\end{tabular}




\begin{tabular}{|c|c|c|c|c|c|c|}
\hline & 24 & Nepal & $1988-2019$ & National Network & Chairperson & M \\
\hline & 25 & Nepal & 2001-2019 & National Network & General Secretary & M \\
\hline & 26 & Pakistan & 2008-2019 & Multilateral Organization & Consultant & $\mathrm{F}$ \\
\hline & 27 & Sri Lanka & 2003-2008 & $\begin{array}{l}\text { Multilateral } \\
\text { Organization/International } \\
\text { Non-Governmental } \\
\text { Organization }\end{array}$ & $\begin{array}{l}\text { Risk and Resilience } \\
\text { Coordinator }\end{array}$ & M \\
\hline & 28 & Sri Lanka & 2004-2010 & $\begin{array}{l}\text { International Non- } \\
\text { Governmental } \\
\text { Organization }\end{array}$ & $\begin{array}{l}\text { Head of Regional } \\
\text { Office }\end{array}$ & M \\
\hline & 29 & Sri Lanka & 2004-2019 & $\begin{array}{l}\text { Multilateral } \\
\text { Organization/International } \\
\text { Non-Governmental } \\
\text { Organization }\end{array}$ & $\begin{array}{l}\text { Head of Department } \\
\text { for Economic Security }\end{array}$ & M \\
\hline \multirow{4}{*}{$\begin{array}{l}\text { Western } \\
\text { Asia } \\
\text { (WAsia) }\end{array}$} & 30 & Lebanon & 2010-2019 & $\begin{array}{l}\text { National Non- } \\
\text { Governmental } \\
\text { Organization }\end{array}$ & $\begin{array}{l}\text { Disaster Risk } \\
\text { Reduction Program } \\
\text { Manager }\end{array}$ & M \\
\hline & 31 & Lebanon & 2018-2019 & $\begin{array}{l}\text { National Non- } \\
\text { Governmental } \\
\text { Organization }\end{array}$ & $\begin{array}{l}\text { Head of Delegation; } \\
\text { Programs Coordinator }\end{array}$ & M \\
\hline & 16 & Yemen & 2015-2019 & $\begin{array}{l}\text { Multilateral } \\
\text { Organization/International } \\
\text { Non-Governmental } \\
\text { Organization }\end{array}$ & $\begin{array}{l}\text { Acting Head of Country } \\
\text { Office; Disaster } \\
\text { Management Delegate }\end{array}$ & M \\
\hline & 32 & Yemen & 2015-2019 & $\begin{array}{l}\text { National Non- } \\
\text { Governmental } \\
\text { Organization }\end{array}$ & Chairman & M \\
\hline
\end{tabular}

